\title{
Circular RNA SMARCA5 Inhibits the Proliferation, Migration, and Invasion of Non-Small Cell Lung Cancer by miR-19b-3p/HOXA9 Axis [Retraction]
}

\author{
Wang Y, Li H, Lu H, Qin Y. Onco Targets Ther. \\ 2019;12:7055-7065.
}

At the authors request, the Editor and Publisher of OncoTargets and Therapy wish to retract the published article. The authors have advised that the information provided for this article was incorrect and no ethics approval was given by the ethics committee of Huaihe Hospital of Henan University and no informed consent was given by any patient involved in the study. This is a breach of our Editorial Polices on research ethics and consent and the Editor has agreed with the decision to retract the paper.

Our decision-making was informed by our policy on publishing ethics and integrity and the COPE guidelines on retraction.

The retracted article will remain online to maintain the scholarly record, but it will be digitally watermarked on each page as "Retracted".

\section{Publish your work in this journal}

OncoTargets and Therapy is an international, peer-reviewed, open access journal focusing on the pathological basis of all cancers, potential targets for therapy and treatment protocols employed to improve the management of cancer patients. The journal also focuses on the impact of management programs and new therapeutic agents and protocols on patient perspectives such as quality of life, adherence and satisfaction. The manuscript management system is completely online and includes a very quick and fair peer-review system, which is all easy to use. Visit http://www.dovepress.com/ testimonials.php to read real quotes from published authors. 